\title{
Comparative evaluation of the DNA damage response in two Peruvian marine bivalves exposed to changes in temperature
}

\author{
Giovanna Sotil $\cdot$ Juan Tarazona $\cdot$ Rafael Alvis $\cdot$ \\ Juan C. Francia · Betty Shiga
}

Received: 29 July 2007 / Revised: 22 October 2007 / Accepted: 27 November 2007 / Published online: 12 January 2008

(C) Springer-Verlag and AWI 2008

\begin{abstract}
The comparison of temperature responses of two mytilids from the high (Brachidontes purpuratus) and low (Semimytilus algosus) intertidal zone of the Peruvian coast was carried out focusing on the production of micronucleus and nuclear abnormalities in gill tissue. Two temperatures $\left(23\right.$ and $\left.11^{\circ} \mathrm{C}\right)$ were evaluated, in presence of three mitomycin $\mathrm{C}$ concentrations as a stressor $\left(0.02,0.04\right.$ and $\left.0.06 \times 10^{-6}\right)$, simulating hypothetical El Niño and La Niña conditions. Responses to extreme temperatures between both species were significantly different $(P=0.008)$. Frequency of micronuclei and nuclear abnormalities in $S$. algosus did not differ statistically among the temperature treatments, whereas in $B$. purpuratus there was an observed significant decrease in nuclear abnormalities $(P=0.012)$ and micronuclei frequencies $(P=0.002)$ between both temperature treatments. The low frequency of micronuclei observed at high temperature and mitomycin $\mathrm{C}$ suggests a better efficiency to stress resistance, as occurs during El Niño events, of the species from the higher intertidal zone of B. purpuratus compared to $S$. algosus from the lower intertidal zone.
\end{abstract}

Communicated by Sven Thatje.

Special Issue: Climate variability and El Niño Southern Oscillation: implications for natural coastal resources and management. S. Thatje (ed.).

G. Sotil · J. Tarazona · R. Alvis · J. C. Francia · B. Shiga

Facultad de Ciencias Biológicas,

Universidad Nacional Mayor de San Marcos,

Av. Venezuela s/n, Lima 1, Peru

G. Sotil $(\bowtie)$

Centro de Investigación de Bioquímica y Nutrición,

Universidad Nacional Mayor de San Marcos, Lima 1, Peru

e-mail: gsotil@yahoo.com
Keywords DNA damage $\cdot$ Micronuclei test . Brachidontes purpuratus - Semimytilus algosus . Temperature stress

\section{Introduction}

The rocky intertidal zone constitutes a stressful environment were organisms are adapted to severe abiotic conditions like desiccation, thermal stress, salinity or exposure to UV radiation. Moreover, and in the particular case of the Peruvian coast, additional thermal variations are related to El Niño and La Niña events. Many marine organisms developed a physiological plasticity to respond to these fluctuating environmental conditions (Gosselin and Chia 1995; Przeslawski 2004), which are expressed for example in biochemical responses, oxygen consumption, reproduction, growth, behavior and in consequence in the distribution of the organisms (Morgan et al. 1999; Langston et al. 2002). The physiological response is related to the genetic regulation at which extreme conditions of stressors, including pollutant exposure, could affect in a negative way at this level (Tikhomirova et al. 1994). This could be inducing the occurrence of mutations (Dixon et al. 2002), with implications over the adaptive population capacities and the decrease of the genetic diversity. For example, high temperatures can induce the increment of DNA damage (Anitha et al. 2000), as well as changes over the expression of heat shock proteins (Dietz and Somero 1992) or oxidative stress (Gosslau et al. 2001). In summary, the effects of physical stressors can be evaluated at a genetic and molecular level (Pigliucci 1996). One of the easiest methods used for the genotoxic evaluation and for biomonitoring of marine environmental conditions, is the analysis of macrolesions occurring in the 
DNA and observed as micronucleus formations (Kim and Hyun 2006). Micronucleus is expressed as an index of chromosomal damage during cell division by the exclusion of DNA strand breaks, mitotic loss of acentric fragments or altered segregation of the whole chromosome from the main nucleus (Dolcetti and Venier 2002). Levels of micronucleus frequency can vary depending on the species, the physiological stage (e.g. age, growth activity) or intensity of the abiotic factors (Brunetti et al. 1992).

Anitha et al. (2000) and Strunjak-Perovic et al. (2003) demonstrated the effect of the heat shock in the induction of micronuclei and DNA strand breaks in fish, while studies in marine bivalve species have particularly focused on the evaluation of DNA damage caused by chemical pollution (Dolcetti and Venier 2002; Dixon et al. 2002; Wrisberg et al. 1992). Studies in gill cells of Mytilus edulis, Mytilus spp., and Mytilus galloprovincialis showed DNA modifications due to chemical stressors (Brunetti et al. 1992). Only few studies have focused on the effects of seasonal changes over micronuclei induction, and no information exists about the effects of thermal changes occurring at this level during El Niño and La Niña.

The aim of our study was to determine if related species occupying different zone levels of the rocky shore have different DNA macrolesions induction at simulated conditions of El Niño and La Niña events. We compared the micronuclei and nuclear abnormalities frequencies of two bivalve species from the low (Semimytilus algosus) and high (Brachidontes purpuratus) intertidal zone. A genotoxic agent mitomycin $\mathrm{C}$ was used in the experiments as a stressor, due to its known cytogenetic damage effect (Majone et al. 1987). We described the successful application of the micronuclei test in gill cells exposed at two temperatures simulating the occurrence of warm and cold-water temperature changes resembling conditions found during $\mathrm{El}$ Niño and La Niña, respectively.

\section{Materials and methods}

Mussels of about $40-50 \mathrm{~mm}$ length of the species S. algosus and B. purpuratus were collected in February and March 2006, from Ancon Bay, Lima, Peru $\left(11^{\circ} 46^{\prime} \mathrm{S}\right.$, $\left.77^{\circ} 11^{\prime} \mathrm{W}\right)$. Organisms were transported to the laboratory and maintained in seawater during $24 \mathrm{~h}$ for acclimatized with $12 \mathrm{~h}$ light-dark cycle. For experimental studies, five organisms per container in $0.5 \mathrm{l}$ of seawater were exposed to temperatures of 11 and $23^{\circ} \mathrm{C}$ during $48 \mathrm{~h}$. Another group of mussels was exposed to three concentrations $0.02,0.04$ and $0.06 \times 10^{-6} \mathrm{M}$ of Mitomycin C (Mitolem, Iemery Laboratory) at the two temperatures, in order to determine if temperature enhances the DNA damage effect of the agent. Treatments were done with repetitions
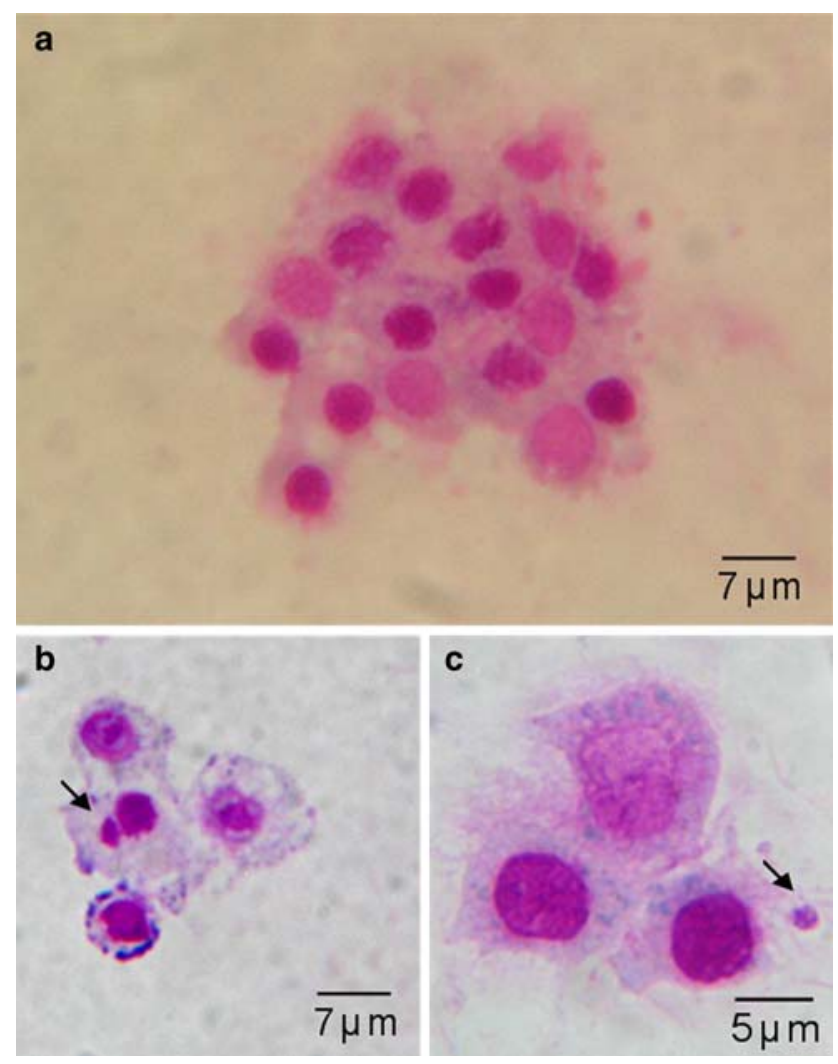

Fig. 1 Nuclear abnormalities (a), binucleated (b) and micronucleated cells (c) observed in gill tissue of $B$. purpuratus exposed to mitomycin at $23^{\circ} \mathrm{C}(\mathbf{a}, \mathbf{b} \times 200 ; \mathbf{c} \times 250)$

and daily water changes. To evaluate the micronuclei frequency, gill tissue was removed, placed in sodium citrate $0.9 \%$ hypotonic solution and cleaned in saline solution CMFS (Calcium magnesium free solution). The suspended cells were filtered with $40 \mu \mathrm{m}$ pore nylon sieves, spread on slides, air-dried, fixed with methanol and stained with Giemsa $2 \%$. Some gill tissues were dissected in the field for the in situ sample analysis and were considered as a normal condition pattern. Six mussels were scored per treatment group. For the micronucleus scoring, we analyzed the large cell type with round uniform chromatin and well preserved cytoplasm. The micronuclei were scored considering the smaller than one-third formations not connected with the main nucleus (according to Wrisberg et al. 1992; Venier et al. 1997). Nuclear abnormalities were quantified considering the three differentiated shapes: kidney shape, fragmented nuclear membrane, and fragmented nuclei (Fig. 1). A total of 1,000 gill cells per mussel were scored per slide, and values were expressed in frequency as number per thousand $(\%$ oo $)$. Mean and standard deviations were calculated per mussel group. Data were transformed to normalized using arcsine of square root of each value. Multiple comparisons were done for evaluating differences among treatments using Tukey test. 
Table $1 P$ values of Tukey test comparing micronuclei and nuclear abnormalities frequencies according to the temperature treatments in S. algosus and B. purpuratus

\begin{tabular}{llllll}
\hline Treatment & \multicolumn{2}{l}{ Micronuclei } & & & \multicolumn{2}{l}{ Nuclear abnormalities } \\
\cline { 2 - 3 } \cline { 5 - 6 } \cline { 5 - 6 } & B. purpuratus & S. algosus & & B. purpuratus & S. algosus \\
\hline In situ vs. $11^{\circ} \mathrm{C}$ & 0.100 & 0.264 & & $0.001^{* *}$ & 0.348 \\
In situ vs. $23^{\circ} \mathrm{C}$ & 1.000 & 0.142 & & 0.060 & 0.797 \\
$11^{\circ} \mathrm{C}$ vs. $23^{\circ} \mathrm{C}$ & $0.005^{* *}$ & 0.854 & & $0.049^{*}$ & 0.460 \\
\hline
\end{tabular}

Significance at $P<0.05^{*}$ and $P<0.005^{* *}$

\section{Results}

Evaluation of micronuclei

A different response in frequency of micronucleated cells was observed according to the intertidal zone distribution of the species. Temperature did not produce statistically significant micronuclei frequencies differences, except when organisms were exposed to mitomycin (Table 1). Average micronuclei values of $S$. algosus groups exposed to low $(1.17 \pm 0.75 \%$ o $)$ and high $(1.58 \pm 1.20 \%$ ) temperatures were higher than the mean of in situ samples $(0.88 \pm$ $1.37 \%$ ). On the other hand, for B. purpuratus mean values in situ samples was $0.33 \pm 0.52$ and $0.83 \pm 0.98 \%$ ofor low and $0.17 \pm 0.41 \%$ o high-temperatures, observing a statistically significant difference $(P=0.005)$ between temperature treatments. The effect of mitomycin on the frequency of micronuclei in both species at the end of the treatment was proportional to the concentrations, except at the highest concentration where frequencies diminished. With the increase of concentration of mitomycin, at $0.04 \times 10^{-6} \mathrm{M}$, and of the temperature were observed the maximum micronuclei frequencies in $S$. algosus with $3.02 \pm 3.14 \%$ and in B. purpuratus with $1.0 \pm 1.41 \%$. At the highest concentration $\left(0.06 \times 10^{-6} \mathrm{M}\right)$ of mitomycin, a reduction in the mean level of micronuclei was detected in $S$. algosus $(2.25 \pm 2.27 \%$ o $)$ and in B. purpuratus $(0.5 \pm 0.84 \%$ ) at $23^{\circ} \mathrm{C}$. Also, the micronuclei frequency of both species varied significantly $(P=0.008)$ according to the temperature exposure (Fig. 2a, b).

\section{Evaluation of nuclear abnormality}

Only for $B$. purpuratus a significant difference was observed between temperature treatments $(P=0.012)$. The maximum average values were observed at $0.04 \times 10^{-6} \mathrm{M}$ of mitomycin, with a significantly difference between the treatments and the in situ samples $(P=0.003)$ (Table 1). Comparing the temperature treatments in this species, the frequency of nuclear abnormalities was of $23 \pm 9.72$ and $20.20 \pm 8.40 \%$ o for 11 and $23^{\circ} \mathrm{C}$, respectively, while the in situ samples showed a frequency of $9.67 \pm 5.28 \%$ o (Fig. 2c, d).
Fig. 2 Micronucleus formations in S. algosus (a) and $B$. purpuratus (b), and nuclear abnormalities in gill cells of S. algosus (c) and B. purpuratus (d) exposed to mitomycin $\mathrm{C}$ at two different temperatures, $11^{\circ} \mathrm{C}$ (circles) and $23^{\circ} \mathrm{C}$ (squares). Asterisk represents the in situ samples and (line) error standard bars of the mean values
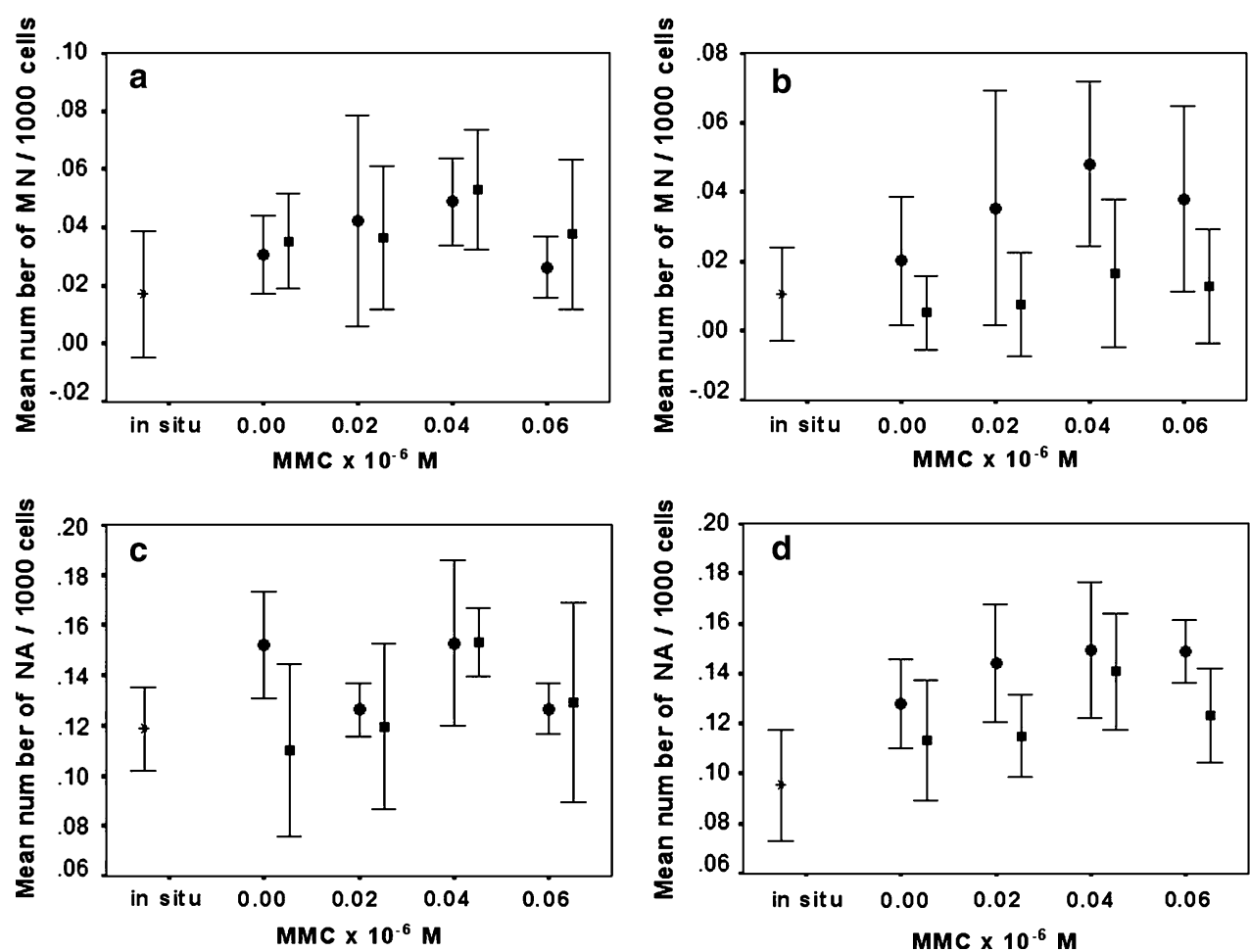


\section{Discussion}

It is known thermal stress affects the structure and function of the centrosome in a negative way (Brown et al. 1996), causing chromosome damages, increment of micronuclei and delay in cell cycle progression, as was reported in the fish Carassius auratus exposed to high temperature (Anitha et al. 2000). In the particular case of bivalve species from the intertidal zone, organisms are exposed to a wide range of environmental changes showing an efficient mechanism for DNA repair, which can explain the slight increase of micronuclei observed when both species were exposed to high and low temperatures, as it was also reported in Mytilus galloprovincialis (Majone et al. 1987).

The latitudinal and vertical distribution of the species is conditioned by their limits of thermal tolerance. Our results demonstrated that different genetic responses under stress exist in species according to their vertical distribution characterizing differences in habitat conditions of both species. The low frequencies of micronuclei and nuclear abnormalities observed in B. purpuratus at high temperature simulating the El Niño event, suggests a better efficiency of the species from the high intertidal zone to adapt to thermal anomalies, as shown by the homogeneous response in this species. Instead, species from the low intertidal zone did not show any differences in response under temperature effects with respect to the simulated conditions for El Niño and La Niña. Wrisberg et al. (1992) mentions that organisms can exhibit different physiological behaviors related to the intensity of a stressor, for example the induction of valve closure in M. galloprovincialis. Organisms can also decrease their metabolic rate, and delay the replication rate of damaged cells, which is related to the reduction of the micronuclei formation (Anitha et al. 2000).

The heat shock impact is increased by the presence of contaminants as mutagenetic agents, producing a strong clastogenic effect. This can explain the decrease of the micronuclei frequency observed in both species at the highest concentrations of mitomycin. Similar results are also reported by Wrisberg et al. (1992) in M. edulis exposed to ethyl methanesulfonate. S. algosus and B. purpuratus are organisms with a sessile behavior and with the capacity of accumulating genotoxic pollutants. Due to these characteristics, both species could represent good bioindicators of changes at the molecular level, caused by the thermal impact of El Niño and La Niña. Alternatively, genetic differences of populations along a latitudinal gradient may lead to variation in the ability to survive and in consequence to different levels of adaptation of the organisms.

\section{Conclusions}

Only B. purpuratus from the high intertidal zone showed a significantly different response in micronuclei and nuclear abnormalities frequencies at the two temperatures evaluated, indicating a better adaptation to extreme thermal conditions in this species. In contrast, the nuclear damage evaluated in S. algosus from the low intertidal zone did not show any significant difference between both temperature treatments. The lack in adaptive response in this species is possibly related to less extreme changes in environmental factors in the lower intertidal area.

Acknowledgments This study was financed and conducted in the frame of the FP6 EU-project CENSOR (Climate Variability and El Niño Southern Oscillation: Implications for Natural coastal Resources and Management, contract 511071) and is CENSOR publication 0316.

\section{References}

Anitha B, Chandra N, Gopinath PM, Durairaj G (2000) Genotoxicity evaluation of heat shock in gold fish (Carassius auratus). Mut Res 469:1-8

Brown C, Brown Q, Doxsey S, Welch W (1996) Molecular chaperones and centrosomes. J Biol Chem 271(2):833-840

Brunetti R, Gabriele M, Valerio P, Fumagalli O (1992) The micronucleus test: temporal pattern of baseline frequency in Mytilus galloprovincialis. Mar Ecol Prog Ser 83:75-78

Dietz T, Somero G (1992) The threshold induction temperature of the $90 \mathrm{kDa}$ heat shock protein is subject to acclimatization in the eurythermal goby fishes (genus Gillichthys). Proc Natl Acad Sci 89:3389-3393

Dixon D, Pruski A, Dixon L, NJha A (2002) Marine invertebrate ecogenotoxicology: a methodological overview. Mutagenesis 17(6):495-507

Dolcetti L, Venier P (2002) Susceptibility to genetic damage and cell types in Mediterranean mussels. Mar Env Res 54:487-491

Gosselin L, Chia F (1995) Characterizing temperate rocky shores from the perspective of an early juvenile snail: the main threats to survival of newly hatched Nucella emarginata. Mar Biol 122:625635

Gosslau A, Ruoff P, Mohsenzadeh S, Hobohm U, Rensing L (2001) Heat shock and oxidative stress-induced exposure of hydrophobic protein domains as common signal in the induction of hsp68. J Biol Chem 276:1814-1821

Kim IY, Hyun CK (2006) Comparative evaluation of the alkaline comet assay with the micronucleus test for genotoxicity monitoring using aquatic organisms. Ecotoxicol Environ Saf 64(3):288-297

Langston A, Hoare R, Stefansson M, Fitzgerald R, Wergeland H, Mulcahy M (2002) The effect of temperature on non-specific defence parameters of three strains of juvenile Atlantic halibut (Hippoglossus hippoglossus L.). Fish Shellfish Immunol 12:61-76

Majone F, Brunetti R, Gola I, Levis A (1987) Persistence of micronuclei in the marine mussel, Mytilus galloprovincialis after treatment of mitomycin C. Mut Res 191:157-161

Morgan I, D'Cruz L, Dockray J, Linton T, Wood C (1999) The effects of elevated summer temperature and sublethal pollutants (ammonia, low $\mathrm{pH}$ ) on protein turnover in the gill and liver of rainbow trout (Onchorhynchus mykiss) on a limited food ration. Comp Biochem Physiol A 123:43-53 
Pigliucci M (1996) How organisms respond to environmental changes: From phenotypes to molecules (and vice versa). Trends Ecol Evol $11: 168-173$

Przeslawski R (2004) A review of the effects of environmental stress on embryonic development within intertidal gastropod egg masses. Mollus Res 24:43-63

Strunjak-Perovic I, Coz-Rakovac R, Topic-Popovic N (2003) Micronucleus occurrence in diploid and triploid rainbow trout (Oncorhynchus mykiss Walbaum). Vet Med 48(8):215-219
Tikhomirova M, Vatti K, Mamon L, Barabanova L, Kutskova Y (1994) Mechanisms underlying the resistance of genetic material of animal cell to stress treatment. Genetika 30(8):1097-1104

Venier P, Maron S, Canova S (1997) Detection of micronuclei in gill cells and haemocytes of mussels exposed to benzo(a)pyrene. Mut Res 390:33-44

Wrisberg M, Bilbo C, Spliid H (1992) Induction of Micronuclei in hemocytes of Mytilus edulis and statistical analysis. Ecotoxicol Environ Saf 23:191-205 